\title{
Pemanfaatan Isi Rumen Sapi yang Difermentasikan dengan Bakteri Bacillus pumilus terhadap Kandungan Klorofil pada Kultur Dunaliella salina
}

\author{
Use of Content Cow Rumen Fermented With Bacillus pumilus \\ Bacterial Chlorophyll Content On The Culture Dunaliella salina
}

\author{
Endang Dewi Masithah, Nur Choiriyah dan Prayogo
}

Fakultas Perikanan dan Kelautan Universitas Airlangga

Kampus C Mulyorejo - Surabaya, 60115 Telp. 031 - 5911451

\begin{abstract}
Dunaliella salina is one type of natural food that can be used in an attempt pembeniha rumen contents of cows is one of the waste obtained from the abattoir which is rich in nutrients. Synthesis of chlorophyll a and b require $\mathrm{N}$ and $\mathrm{P}$. The purpose of this study was to determine the effect and the best dose utilization of rumen contents of cows and Bacillus pumilus in the culture of Dunaliella salina in chlorophyll content. The research design used was Completely Randomized Design (CRD) followed by Duncan multiple range test. Treatment research Dunaliella salina was cultured in $500 \mathrm{~mL}$ glass bottle with 5 treatments and 4 replications. Culture medium used was sea water that has salinity $30 \mathrm{ppt}$ as much as 0.5 liters of rumen fluid is added $0.5 \mathrm{ml}$ of solution that has been fermented with Bacillus pumilus in accordance with the treatment dose. The results showed that the use of fermenter bacteria Bacillus pumilus in cow rumen contents effect on chlorophyll content and dose fermenter rumen bacterium Bacillus pumilus in cattle that give the best chlorophyll content in Dunaliella salina culture fermentation is the dose intreatmentC(7.5\%dosefermentation)reached 0.715653211 a $\mu$ molchl/cell on the first day.
\end{abstract}

Keywords : Dunaliella salina, cow rumen, Bacillus pumilus, chlorophyll

\section{Latar Belakang}

Dunaliella salina merupakan salah satu jenis Chlorophyceae yang sering disebut flagellata hijau bersel satu (green unicellulair flagellate) yang mempunyai klorofil a dan b, selain itu juga sebagai pakan alami pada pembenihan ikan. Manfaat dari Dunaliella salina antara lain adalah sebagai pakan alami dan sebagi zat antioksidan bagi manusia. Lobban and Harrison (1994) dalam Kim et al. (2007) menyatakan bahwa sintesis klorofil $a$ dan $b$ memerlukan N. Selain N dan P, pembentukan klorofil a juga dipengaruhi oleh Magnesium (Mg). $\mathrm{Mg}$ merupakan unsur yang membentuk struktur klorofil dan berperan dalam penangkapan cahaya dalam proses fotosintesis (Lawlor, 1993). Harrison and Berges (2005) menyatakan bahwa salah satu cara untuk meningkatkan pertumbuhan fitoplankton adalah mengontrol kandungan nutrien baik makro maupun mikro pada lingkungan budidaya.

Isi rumen sapi adalah salah satu limbah yang diperoleh dari rumah potong hewan yang kaya akan nutrisi. Limbah ini sebenarnya sangat potensial bila dimanfaatkan sebagai pupuk karena isi rumen memiliki nutrisi tinggi.

Bakteri Bacillus pumilus merupakan bakteri selulolitik yang memiliki kemampuan mendegadrasi serat kasar menjadi glukosa dan asam laktat (Gunawan dan Sundari, 2003). Guna meningkatkan kualitas isi rumen sapi maka dilakukan proses fermentasi menggunakan bakteri Bacillus pumilus. dalam penelitian ini dilakukan studi sejauh mana kesuburan D. salina berdasarkan kandungan klorofilnya dengan menggunakan pupuk isi rumen sapi yang difermentasi dengan bakteri Bacillus pumilus dengan dosis berbeda.

\section{Tujuan}

Untuk mengetahui apakah penggunaan bakteri Bacillus pumilus pada rumen sapi dapat meningkatkan kandungan klorofil pada kultur Dunaliella salina.

Untuk mengetahui berapa dosis fermentor bakteri Bacillus pumilus pada rumen sapi yang memberikan kandungan klorofil Dunaliella salina tertinggi.

\section{Materi dan Metode Penelitian}

Waktu dan Tempat

Kegiatan penelitian ini dilaksanakan pada bulan September - Oktober 2010 di Laboratorium Perikanan, Fakultas Perikanan dan Kelautan, Unair.

Materi Penelitian

Materi penelitian yang akan digunakan terdiri atas bahan dan alat penelitian. Bahan penelitian yang digunakan adalah adalah Dunaliella salina dari BBAP Situbondo, rumen yang didapat dari RPH Pegirian, Bacillus pumilus isolat dari Lamit (Unair, 2009). Pupuk komersial Walne, air laut dan air tawar, aquadest, Chlorine dan $\mathrm{Na}$ Thiosulfat, amonium sulfat, aceton $90 \%, \mathrm{MgCO}_{3}$, media untuk 
peremajaan Bacillus pumilus (g/L): Pepton 5,0; Yeast Ekstrak1,0; K2HPO4 1,0; MgSO4 7H2 O 0,2; media yang diperkaya xilan $10,0 \%(\mathrm{w} / \mathrm{v}) ; 0,5 \mathrm{~mL}$ spelt xylan $1 \%(\mathrm{w} / \mathrm{v})$, tetes tebu, alkohol. Peralatan yang digunakan dalam penelitian adalah spektrofometer, toples kaca, aerator, selang aerator, gabus, plastik, gelas ukur, pipet tetes, mikroskop, Sedgewich Rafter (50 mm x $20 \mathrm{~mm}$ x $0.1 \mathrm{~mm})$, Handtally Counter, autoclave, Refraktometer, $\mathrm{pH}$ universal, pipet volume, galon, amonia test, kapas, corong air, sentrifuge, elenmeyer, timbangan, termometer, $\mathrm{pH}$ universal, lampu TL, kasa, aluminium foil dan kertas saring.

\section{Metode Penelitian}

Rancangan penelitian yang digunakan dalam penelitian adalah Rancangan Acak Lengkap (RAL), penelitian terdiri dari Perlakuan A (dosis $12.5 \%$ ), B (dosis $10 \%$ ), C (dosis 7,5\%), kontrol 1 (tanpa fermentasi) dan kontrol 2 (pupuk walne). Setiap perlakuan mendapat ulangan sebanyak 4 kali.

Prosedur Kerja

Sterilisasi

Sterilisasi alat dan air laut dimaksudkan untuk menghindari adanya kontaminasi mikroorganisme lain. Peralatan yang akan digunakan dicuci sampai bersih kemudian dibilas dengan air tawar. Peralatan yang sudah bersih direndam dengan larutan klorin $150 \mathrm{mg} / \mathrm{L}$ selama 24 jam. Setelah itu, peralatan dikeringkan di bawah sinar matahari. Peralatan yang akan digunakan untuk kultur disterilkan dengan menggunakan autoclave dengan suhu $121^{\circ} \mathrm{C}$ selama 15 menit. Sterilisasi dengan autoclave dilakukan untuk peralatan yang terbuat dari kaca tahan panas.

Air laut sebagai media kultur juga disterilkan dengan larutan klorin. Air laut disaring dengan kapas yang diletakkan dalam corong air, lalu disterilkan dengan klorin $60 \mathrm{mg} / \mathrm{L}$ selama 24 jam. Na Thiosulfat $20 \mathrm{mg} / \mathrm{L}$ diberikan untuk menghilangkan sisa-sisa bau klorin. Air laut yang telah steril disimpan dalam wadah yang tidak tembus cahaya dan tertutup. Hal ini dimaksudkan agar tidak tumbuh lumut atau mikroorganisme lain (Ekawati, 2005).

\section{Persiapan Rumen}

Rumen yang digunakan untuk penelitian diperoleh dari limbah Rumah Potong Hewan, Pegirian, Surabaya. Rumen yang akan digunakan dikeringkan dengan terik sinar matahari sampai kering kemudian dihaluskan. Kandungan $\mathrm{N}$ dan $\mathrm{P}$ pada rumen sapi yang belum difermentasi kemudian dianalisis.

\section{Persiapan Bacillus pumilus}

Isolat Bacillus pumilus yang digunakan adalah isolat yang diisolasi oleh Lamit (Unair, 2009) dari Rumen sapi. Adapun persiapan untuk isolat Bacillus pumilus yaitu dengan menyediakan media cair untuk menghasilkan xilanase. Komposisi untuk membuat media cair yang diperkaya xilan $(\mathrm{g} / \mathrm{L})$ yaitu : Xilan 10,01\% (w/v); Pepton 5,0; Yeast Ekstrak1,0; $\mathrm{K}_{2} \mathrm{HPO}_{4} 1,0 ; \mathrm{MgSO}_{4} 7 \mathrm{H}_{2} \mathrm{O}$ 0,2. Sebelum digunakan untuk fermentasi, dianalisis TPC untuk mengetahui kepadatan bakteri (metode Mc farlan).

Fermentasi Rumen Dengan Bacillus pumilus

Rumen sapi yang telah kering dan sudah ditimbang sebanyak 5 gram difermentasi menggunakan isolat Bacillus pumilus. Sebagai aktivator adalah tetes. Proses ini diawali dengan mencampur $4 \%$ tetes, $1,5 \mathrm{~mL}$ air, 5 gram isi rumen sapi dan isolat Bacillus pumilus dengan dosis sesuai perlakuan, kemudian diaduk secara merata. Sesudah itu dimasukkan dalam plastik hitam dan diinkubasi selama 5,7, dan 9 hari dengan suhu $27-32^{\circ} \mathrm{C}$. Setelah mencapai jangka waktu fermentasi yang ditentukan, rumen yang telah difermentasi dikeringkan dan siap digunakan.

Persiapan Pembuatan Stok Rumen Terfermentasi Bacillus pumilus

Rumen yang sudah kering dan telah difermentasi dengan isolat Bacillus pumilus ditimbang sebanyak $5000 \mathrm{mg}$, kemudian rumen tersebut dilarutkan dalam $500 \mathrm{~mL}$ aquadest. Konsentrasi larutan rumen yang digunakan dalam penelitian ini adalah $10 \mathrm{ppm}$ dengan volume penggunaan $1 \mathrm{~mL} / \mathrm{L}$. Kemudian larutan rumen dimasukkan ke dalam erlenmeyer sambil disaring dengan kertas saring. Erlenmeyer yang berisi rumen ditutup dengan gause (kapas yang dibalut dengan kasa) dan dibalut dengan aluminium foil lalu disterilkan menggunakan autoclave. Pembuatan cairan rumen terfermentasi isolat Bacillus pumilus untuk kultur Dunaliella salina menggunakan rumus :

$$
Q=\frac{V}{P} \times K \quad \text { (Satyantini dan Masithah, 2008) }
$$

Keterangan:

$\mathrm{Q}=$ berat bahan yang dilarutkan (mg, gram)

$\mathrm{V}=$ volume pelarut/ aquadest $(\mathrm{ml}, \mathrm{L})$ 
$\mathrm{P}=$ volume penggunaan dalam media kultur $(\mathrm{ml} / \mathrm{L})$

$\mathrm{K}=$ konsentrasi pupuk yang diketahui $(\mathrm{ppm}, \mathrm{mg} / \mathrm{L})$

Media Kultur dan Lingkungan Dunaliella salina Media kultur yang digunakan dalam penelitian adalah air yang mempunyai salinitas 30 ppt sebanyak 0.5 liter yang dimasukkan dalam toples kaca. Selanjutnya ditambahkan $0,5 \mathrm{ml}$ larutan rumen yang telah difermentasi dengan Bacillus pumilus sesuai dengan dosis perlakuan. Kemudian media kultur diletakkan di rak kultur lalu diberi aerasi dan siap dimasukkan bibit Dunaliella salina dengan kepadatan yang diinginkan.

Lingkungan kultur dapat mempengaruhi pertumbuhan Dunaliella salina, oleh karena itu lingkungan dikondisikan sama untuk setiap perlakuan. Lingkungan kultur Dunaliella salina dalam penelitian ini adalah suhu $25-30^{\circ} \mathrm{C}$, salinitas 30 - 32 ppt, intensitas cahaya $1300-2300$ lux, pH 7 - 9 dan photoperiod 18 jam dalam keadaan terang dan 6 jam dalam keadaan gelap (Yurong, 2005). Rak kultur ditutup dengan plastik hitam, agar suhu ruang stabil, untuk menghindari kontaminan, dan untuk mengatur fotoperiod.

\section{Penebaran bibit Dunaliella salina}

Dunaliella salina yang digunakan untuk penelitian diperoleh dari Balai Besar Budidaya Air Payau Situbondo dan Jepara. Bibit Dunaliella salina murni kemudian dimasukkan ke dalam botol sesuai dengan kepadatan sebesar $500.000 \mathrm{sel} / \mathrm{ml}$. Penghitungan jumlah bibit Dunaliella salina yang diperlukan untuk kultur, dapat menggunakan rumus sebagai berikut:

$$
V 1=\frac{N 2 \times V 2}{N 1} \quad(\text { Ekawati, 2005) }
$$

Keterangan:

$\mathrm{V} 1=$ Volume bibit untuk penebaran awal $(\mathrm{ml})$

N1 = Kepadatan bibit/ stock Dunaliella salina (unit/ ml)

$\mathrm{V} 2=$ Volume media kultur yang dikehendaki (L)

N2 = Kepadatan bibit Dunaliella salina yang dikehendaki (unit/ ml)

Penghitungan Klorofil

Pengukuran kandungan klorofil $D$. salina dilakukan menggunakan spektrofotometer dengan metode modifikasi dari Lobban et al., 1988. Sampel diambil sebanyak $80 \mathrm{ml}$, selanjutnya dihitung kepadatan sel per $\mathrm{ml}$ D. salina. Sampel dibagi menjadi 8 bagian (kode A-H), masing-masing sebanyak $10 \mathrm{ml}$ dan dimasukkan ke dalam cuvet sentrifuge. Sampel disentrifuge dengan kecepatan 5000 rpm selama 5 menit.

Setelah proses sentrifuge selesai, supernatan dibuang hingga tersisa pelletnya. Sampel A ditambah $\mathrm{MgCO}_{3}$ dan $1 \mathrm{ml}$ acetone 90\% untuk proses ekstraksi. Sample dihomogenkan secara manual selama kurang lebih 10-15 menit. Sample kode A (1 tabung) merupakan blanko. Sedangkan pellet dari sample kode B-H (7 tabung), dijadikan satu dalam satu kuvet, selanjutnya ditambahkan $\mathrm{MgCO}_{3}$ dan $1 \mathrm{ml}$ acetone 90\%. Sample tersebut merupakan sample kandungan klorofil yang akan dihitung pada spektrofotometer.

Sebelum digunakan, spektrofotometer dikaliberasi terlebih dahulu, sesuai dengan panjang gelombang yang akan digunakan yaitu $\mathrm{A}_{664}$ dan $\mathrm{A}_{647}$. Selanjutnya blanko dan sample diukur serapan cahayanya pada spektrofotometer. Selanjutnya kandungan klorofil dihitung menggunakan rumus berikut :

1. Kandungan klorofil-a dan klorofil-b (larutan aceton 90\%) :

a) Klorofil-a $=11,93 \mathrm{~A}_{664}-1,93 \mathrm{~A}_{647}$

b) Klorofil-b $=20,63_{\mathrm{A} 647}-5,50_{\mathrm{A} 664}$

2. Jumlah untuk $\mu \mathrm{g}$ chl cell $^{-1}$ dari fitoplankton :

$$
\text { Mol dari chl ekstrak }=\frac{\mu \mathrm{g} \text { chl dalam ekstrak }}{\text { berat molekul dari chl }}
$$

(Berat molekul : chl-a 894, chl-b 908)

Parameter Pengamatan

Parameter Utama

Parameter utama dalam penelitian ini adalah jumlah klorofil dalam kultur Dunaliella salina yang telah dikultur dengan pupuk fermentasi rumen sapi dengan isolat bakteri Bacillus pumilus.. Perhitungan kandungan klorofil Dunaliella salina dilakukan pada hari pertama, ketiga dan kelima. Perhitungan kandungan klorofil dihitung dengan menggunakan Spekttofotometer.

\section{Parameter Pendukung}

Parameter pendukung dalam penelitian adalah kepadatan populasi Dunaliella salina, suhu, $\mathrm{pH}$, salinitas. Perhitungan terhadap suhu, $\mathrm{pH}$, salinitas dilakukan setiap hari. Parameter pendukung digunakan untuk melengkapi data dari parameter utama.

\section{Analisis Data}

Data penelitian dianalisis secara statistik dengan menggunakan ANAVA. Bila terdapat 
perbedaan dapat dilakukan uji lanjutan. Untuk mengetahui signifikasi pengaruh perlakuan satu dengan perlakuan yang lain dapat dilakukan uji lanjutan yaitu dengan Uji Jarak Berganda Duncan (Duncan's Multiple Range Test) (Kusriningrum, 2008).

\section{Hasil dan Pembahasan}

Hasil Penelitian

Data kandungan klorofil dan hasil analisis varian (ANAVA) yang ditunjukkan pada tabel 1 menunjukan bahwa masing-masing perlakuan memberikan pengaruh yang berbeda nyata $(\mathrm{p}<0,05)$ terhadap kandungan klorofil Dunaliella salina.

Kualitas Air

Parameter kualitas air yang diukur selama penelitian adalah suhu $\left({ }^{\circ} \mathrm{C}\right), \mathrm{pH}$ dan salinitas. Hasil pengukuran suhu selama penelitian pada setiap perlakuan dan ulangan yaitu berkisar antara $26-28^{\circ} \mathrm{C}$. $\mathrm{pH}$ berkisar antara 7-8. Salinitas pada setiap perlakuan berkisar sampai $45 \%$.

Tabel 1. Hasil uji jarak berganda Duncan terhadap jumlah klorofil a Dunaliella salina

\begin{tabular}{ccc}
\hline Perlakuan & $\begin{array}{c}\text { Jumlah klorofil } a \text { rata-rata akhir } \\
\text { penelitian }(\mu \mathrm{g} / \mathrm{ml})\end{array}$ & $\begin{array}{c}\text { Jumlah klorofil } a \text { rata-rata akhir } \\
(\text { Transformasi } \sqrt{ } \mathrm{Y})\end{array}$ \\
\hline Kontrol 1 (tanpa fermentasi) & $0,0072^{\mathrm{c}}$ & $0,71215354^{\mathrm{c}}$ \\
Kontrol 2 (walne) & $0,0125^{\mathrm{a}}$ & $0,715910532^{\mathrm{a}}$ \\
Perlakuan A (dosis 12,5\%) & $0,0090^{\mathrm{b}}$ & $0,713429377^{\mathrm{b}}$ \\
Perlakuan B (dosis 10\%) & $0,0097^{\mathrm{b}}$ & $0,713907734^{\mathrm{b}}$ \\
Perlakuan C (dosis 7,5\%) & $0,0122^{\mathrm{a}}$ & $0,715653211^{\mathrm{a}}$ \\
\hline
\end{tabular}

Tabel 2. Hasil uji jarak berganda Duncan terhadap jumlah klorofil b Dunaliella salina

\begin{tabular}{ccc}
\hline Perlakuan & $\begin{array}{c}\text { Jumlah klorofil } b \text { rata-rata akhir } \\
\text { penelitian }(\mu \mathrm{g} / \mathrm{ml})\end{array}$ & $\begin{array}{c}\text { Jumlah klorofil } b \text { rata-rata akhir } \\
(\text { Transformasi } \sqrt{ } \mathrm{Y})\end{array}$ \\
\hline Kontrol 1 (tanpa fermentasi) & $0,0103^{\mathrm{b}}$ & $0,71215354^{\mathrm{c}}$ \\
Kontrol 2 (walne) & $0,0178^{\mathrm{a}}$ & $0,715910532^{\mathrm{a}}$ \\
Perlakuan A (dosis 12,5\%) & $0,0117^{\mathrm{ab}}$ & $0,713429377^{\mathrm{b}}$ \\
Perlakuan B (dosis 10\%) & $0,0179^{\mathrm{a}}$ & $0,713907734^{\mathrm{b}}$ \\
Perlakuan C (dosis 7,5\%) & $0,0184^{\mathrm{a}}$ & $0,715653211^{\mathrm{a}}$ \\
\hline
\end{tabular}

Kandungan Nutrisi Rumen Sapi

Hasil uji laboratorium kadar nitrogen dan phosphor sebelum fermentasi adalah 1,5413 dan 1,22. Kadar unsur nitrogen rumen sapi setelah fermentasi menggunakan bakteri Bacillus pumilus terjadi peningkatan menjadi 1,5415\% sedangkan kadar unsur phosphor mengalami penurunan menjadi $0,345 \%$.

Hasil perhitungan Anava pada penelitian pemberian pupuk fermentasi isi rumen sapi dengan Bacillus pumilus berpengaruh nyata $(\mathrm{p}<0,05)$ terhadap jumlah klorofil $a$ dan $b$ D.salina. Hasil menunjukkan bahwa pupuk fermentasi isi rumen sapi dengan Bacillus pumilus yang dapat memberikan jumlah klorofil $a$ dan $b$ D.salina terbaik adalah perlakuan $\mathrm{C}$ (dosis 7,5\%) yang tidak berbeda nyata ( $>0,05)$ dengan kontrol 2 (pupuk walne), dan perlakuan A (dosis 12,5\%) tidak berbeda nyata $(\mathrm{p}>0,05)$ dengan perlakuan B (dosis 10\%). Hasil terendah pada perlakuan kontrol 1 (tanpa fermentasi).
Hal ini menunjukkan bahwa pemberian pupuk fermentasi isi rumen sapi dengan Bacillus pumilus memberikan pengaruh yang berbeda terhadap jumlah klorofil $a$ dan $b$ D.salina antara perlakuan. Diduga bahwa adanya perbedaan antara perlakuan yang menggunakan pupuk fermentasi dengan yang tanpa fermentasi karena pada perlakuan tanpa fermentasi, penambahan unsur hara tersedia bagi plankton, tidak sebanyak pada perlakuan yang menggunakan fermentasi.

Kandungan klorofil D.salina terendah terjadi pada perlakuan kontrol 1 (tanpa fermentasi oleh bakteri). Hal ini diduga disebabkan nutrien tersedia yang digunakan untuk pembentukan klorofil lebih sedikit dibanding perlakuan dengan bakteri fermentasi. Bakteri fermentasi membantu proses degradasi bahan organik (rumen sapi) menjadi nutrien tersedia, sehingga pertumbuhan dan klorofil D.salina meningkat. Hal ini sesuai dengan pendapat Aslan (1998) bahwa salah satu faktor yang mempengaruhi pertumbuhan D.salina adalah nutrien 
yang dapat diperoleh dari pupuk. Denault et al., (2000) juga menyatakan bahwa jumlah klorofil $a$ menurun seiring dengan menurunnya hara pada media pemeliharaan. Kurangnya unsur hara dapat menyebabkan proses fotosintesis terhambat dan berpengaruh terhadap jumlah klorofil (Latif, 2008).

Faktor utama yang dibutuhkan untuk pembentukan klorofil $a$ dan $b$ adalah nutrien dan cahaya. Aslan (1998) menyatakan bahwa pertumbuhan dan perkembangan mikroalga membutuhkan kualitas cahaya serta nutrien yang cukup seperti nitrat dan fosfat. Nitrat dan fosfat diperlukan sebagai bahan dasar penyusun protein dan pembentukan klorofil dalam proses fotosintesis. Klorofil adalah zat pembawa warna hijau pada tumbuhan (Carter, 1996). Komponen utama penyusun klorofil adalah $\mathrm{N}$ dan $\mathrm{Mg}$ (Lawlor, 1993). $\mathrm{N}$ diperlukan sebagai bahan dasar penyusun protein dan pembentukan klorofil dalam fotosintesis. Semakin banyak pembentukan klorofil maka proses fotosintesis semakin optimal (Jadid, 2008).

Analisis kandungan nitrogen $(\mathrm{N})$ dan fosfor (P) menunjukan bahwa terjadi peningkatan rasio $\mathrm{N}: \mathrm{P}$ setelah fermentasi dari 1,26:1 menjadi 4,47:1. Peningkatan rasio N:P ini menyebabkan kandungan nutrisi rumen setelah fermentasi menjadi lebih sesuai bagi pertumbuhan D. salina walaupun belum ideal. Menurut Shoni (2006) rasio N:P ideal untuk pertumbuhan Chlorophyceae adalah 10-20:1. Unsur $\mathrm{N}$ merupakan komponen penting bagi pertumbuhan plankton (Anggadireja dkk., 2006). Hal ini disebabkan $\mathrm{N}$ merupakan faktor pembatas bagi pertumbuhan mikrolaga (Hanisak, 1983). Novizan (2000) dalam Latif (2008) menyatakan bahwa unsur $\mathrm{N}$ di dalam perairan menyebabkan tanaman tumbuh subur, sehingga produksinya meningkat.

Selain unsur N, Dunaliella salina juga membutuhkan unsur fosfor (P) dalam pertumbuhannya. Khul (1974) dalam Susanto dkk. (2001) menyatakan bahwa penambahan P diperlukan untuk pembentukan ATP dan berperan dalam penyerapan ion oleh mikroalga.

Faktor cahaya, diduga tidak menjadi faktor yang menyebabkan perbedaan hasil pada penelitian ini. Hal ini disebabkan, pencahayaan telah diatur merata dan sesuai dengan kebutuhan D. salina, seperti pendapat Isnansetyo dan Kurniastuty (1995) bahwa $D$. salina optimum pada pencahayaan 13002300 lux.

Pertumbuhan plankton juga dipengaruhi faktor eksternal (Kamlasi, 2006). Suhu merupakan salah satu faktor yang penting bagi pertumbuhan rumput laut (Raikar et al., 2001). Hal ini disebabkan suhu mempengaruhi aktivitas metabolisme dan perkembangan suatu organisme (Sahabuddin dan Tangko, 2008). Hasil pengukuran suhu selama penelitian berkisar antara $26-28^{\circ} \mathrm{C}$. Aslan (1998) menyatakan bahwa suhu yang baik untuk pertumbuhan mikroalga berkisar antara $26-33^{\circ} \mathrm{C}$.

Salinitas yang terukur selama penelitian berkisar antara 34 - 45\%. Chen (1994) menyatakan bahwa salinitas optimal bagi pertumbuhan Dunaliella adalah 20-35\%. Penurunan dan peningkatan salinitas di atas batas optimum tidak menyebabkan kematian, tetapi mengakibatkan pertumbuhan akan terhambat (Syafruddin, 1993 dalam Latif, 2008)

Power of Hydrogen $(\mathrm{pH})$ adalah suatu ukuran dari konsentrasi ion hidrogen dan menunjukkan sifat asam atau basa suatu perairan (Summerfelt, 1997). Power of Hydrogen $(\mathrm{pH})$ air selama penelitian berkisar antara 7-8. Aslan (1998) menyatakan bahwa pH optimum bagi mikroalga berkisar antara 6,8-8,2 Kualitas air pemeliharaan D.salina selama penelitian dapat disimpulkan masih layak dan sesuai kebutuhan hidup D.salina.

\section{Kesimpulan}

Penggunaan fermentor bakteri Bacillus pumilus pada rumen sapi berpengaruh nyata terhadap kandungan klorofil pada kultur Dunaliella salina Dosis fermentor bakteri Bacillus pumilus pada rumen sapi yang memberikan kandungan klorofil terbaik pada kultur Dunaliella salina adalah dosis fermentasi pada perlakuan $\mathrm{C}$ (dosis fermentasi 7,5\%) mencapai $0,715653211^{\mathrm{a}} \mu \mathrm{mol} \mathrm{chl} / \mathrm{sel}$.

Isi rumen sapi yang di fermentasi dengan Bacillus pumilus (5 g rumen sapi, tetes $4 \%$ dan 1,5 $\mathrm{mL}$ air) sebagai pupuk dalam kultur Dunaliella salina memiliki nilai $\mathrm{N}$ yang cukup tinggi dan mampu menyediakan unsur hara, namun nilai $\mathrm{P}$ yang

rendah. Nilai $\mathrm{P}$ yang rendah tersebut dapat ditingkatkan dengan penambahan dari sumber nutrient lainnya. Namun masih perlu dilakukan penelitian lebih lanjut mengenai penambahan phosphor dari nutrient yang berbeda yang bisa meningkatkan kandungan klorofil Dunaliella salina yang lebih baik lagi. Sterilisasi alat dan lingkungan kultur meliputi suhu, $\mathrm{pH}$ dan salinitas sebaiknya dalam kondisi terkontrol.

\section{Daftar Pustaka}

Beker. E. W. 1994. Microalgae Biotechnology and Microbiology. Cambrige University Press 
Ben-Amotz, A. 1993. Production of $\beta$ - carotene and Vitamins by The Halotolerant Alga Dunaliella. Marine Biotechnology Vol 1. Pharmaceutical and Bioactive Natural Products. Ed. Attaway, D.H. \& Zaborsky, O.R. Enum. 411- 416p

Borowitzka, M. A. 1990. The Mass Culture of Dunaliella salina. http://www.fao.org. 09/08/2009. 16 hal.

Edhy,. W. A., J. Pribadi dan Kurniawan. 2003. Plankton. PT. Central Pertiwi Bahari. Kalimantan Barat. Hal. 1 - 29.

Ekawati, A. W. 2005. Diktat Kuliah Budidaya Pakan Alami. Fakultas Perikanan Universitas Brawijaya. Malang. Hal. 3 - 48.

El Bas, F. K., Ahmed M, Aboul E, Gamal S. 2002. Accumulation of Antioxidant Vitamins in Dunaliella salina. www.sciencedirect.com. 10/08/2009. 4pp.

Gunawan dan Sundari. 2003. Pengaruh Penggunaan Probiotik dalam Ransum terhadap P r o d u k t i v t a s A y m. http://peternakan.litbang.deptan.go.id/1332.pdf. 25/10/2009. 7 hal

Ivanova , E.P, Vysostskii, Mv.< sSvestashev, V.I., Nedakashkovskaya, O.I. ; Gorshkova, N.M., Mikhailov, V.V; N.; Shigeri, yoshikawa, S (1999). Characterisation of Bacillus strains of marine origin. Int.Microbiol 267-271

Gusrina. 2009. Makalah Budidaya Pakan Alami (Phytoplankton, Zooplankton dan Benthos). http://ardivedca.blogspot.com/makalahbudidaya-pakan-alami_08.html. 3/11/2009. 22 hal

Hosei. 2008 . Dunaliella salina. http://protist.i.hosei.ac.jp/Dunaliella/salina 1.jpg. 10/11/2009.1 hal.

Isnansetyo, A. dan Kurniastuty. 1995. Ateknik Kultur Fitoplankton dan Zooplanton. Penerbit Kanisius. Yogyakarta. hal. $46-85$.

Jemiati. 2002. Pengaruh Perbedaan Salinitas Terhadap Pertumbuhan Chlorella sp. pada Media yang Diperkaya Dengan Limbah Pabrik Gula. Skripsi. Fakultas Perikanan Universitas Brawijaya. Malang. hal. 1 - 46.
Kusriani dan E. Yuli. 2005. Buku Ajar Planktonologi. Fakultas Perikanan Universitas Brawijaya. Malang. hal. $1-41$.

Kusriningrum, R. S. 2008. Perancangan Percobaan. Universitas Airlangga. Surabaya. Hal. 165 173.

Lamid, Mirni., Chuzaemi, Siti., Puspaningsih, Ni Nyoman Tri., dan Kusmartono. 2006. Inokulasi Bakteri Xilanolitik Asal Rumen sebagai Upaya Peningkatan Nilai Nutrisi Jerami Padi. Fakultas Kedokteran Hewan Universitas Airlangga. Surabaya. http//www.mirnilamid@yahoo.com. 11/03/2010. 7 hal.

Nurjariah. 2005. Kelimpahan Bakteri dalam Budidaya Cacing Sutera Limnodrilus sp. Yang Dipupuk Kotoran Ayam Hasil Fermentasi. Skripsi. Institut Pertanian Bogor. Bogor. 34 hal.

Richmond, A. 1988. CRC Handbook of Mikroalgal Mass Culture. CRC Press Ino. Florida. p. $156-190$.

Satyantini, W. H. dan E. D. Masithah. 2008. Diktat Penuntun Praktikum Budidaya Pakan Alami. Fakultas Perikanan dan Kelautan Universitas Airlangga. Surabaya. hal. 28 49.

Sylvester, B. D., Nelvy D dan Sudjiharno. 2002. Persyaratan Budidaya Fitoplankton. dalam Budidaya Fitoplankton dan Zooplankton. 2002. Balai Budidaya Laut, Direktorat Jenderal Perikanan Budidaya Departemen Kelautan dan Perikanan. Bandar Lampung. Hal.24 - 36 .

Tjahjo, W., L. Erawati dan Hanung, S. 2002. Biologi Fitoplankton. dalam Budidaya Fitoplankton dan Zooplankton. 2002. Balai Budidaya Laut, Direktorat Jenderal Perikanan Budidaya Departemen Kelautan dan Perikanan. Bandar Lampung. Hal.3 - 23. 